\title{
Detection of Financial Statement Fraud with The Fraud Pentagon Method for Mining Sector Companies Listed on Indonesian Stock Exchange (IDX) for period 2012 to 2018
}

\author{
Sebastianus T. Lamawitak ${ }^{1}$, Sarinah Joyce M. Rafael ${ }^{2}$, Karmila D.L. Mutia ${ }^{3}$ \\ \{sebastiantheodosy@gmail.com ${ }^{1}$, joyce.rafael@staf.undana.ac.id ${ }^{2}$, milamutia@staf.undana.ac.id ${ }^{3}$ \}
}

Faculty of Economics and Business, University of Nusa Cendana, Kupang, Indonesia ${ }^{1,2,3}$

\begin{abstract}
The purpose of this study was to determine the detection of financial statement fraud using the Pentagon fraud method in mining sector companies listed on IDX during 2012 to 2018. This study used five (5) independent variables, namely pressure on financial stability, oppurtunity on nature of industry, rationalization on total accrual ratio, competence on change in CEO, and arrogance on dualism position of CEO and financial statement fraud as dependent variable that is proxied by earnings management. Sample in this study using purposive sampling method with the final sample is fifteen (15) mining sector companies listed on IDX during 2012 to 2018. The results of this study are pressure on financial stability, oppurtunity on nature of industry, rationalization on total accrual ratio, competence on change in CEO, and arrogance om dualism position of CEO partially does not significantly influence financial statement fraud and smultaneously does significantly influence financial statement fraud
\end{abstract}

Keyword: financial statement fraud, fraud pentagon, pressure, oppurtunity, rationalization, competence, arrogance, earnings management, financial stability, nature of industry, total accrual ratio, change in $\mathrm{CEO}$, dualism position of CEO

\section{Introduction}

Fraud is a term that we often hear, but some people will be unfamiliar with the term. Based on Statement of Auditing standards (SAS) No. 99 issued by the American Institute of Certified Public Accountants (AICPA) in 2002 fraud was "intentional act that results in material misstatement in financial statements that are subject to an audit ". In the business world a fraud besides causing financial losses can also worsen the image of a company in the eyes of shareholders, investors and other interested parties. Viewed from accounting point of view, fraud is called the top-level crime or white collar crime.

In the 2018 Report To The Nations published by the ACFE on Global Study on Occupational Fraud and Abuse, reported that there were 2,690 cases of fraud found throughout the world, of which 29 cases were found in Indonesia. The report also shows that financial statement fraud is the least number of cases, namely $10 \%$ or 269 cases of all cases that have occurred, but causes the highest losses of $\$ 800,000$ per case. ACFE Indonesia collaborated with the White Collar Crime Prevention and Research Center to conduct fraud surveys in Indonesia. In 2016 Indonesian Fraud Survey, 178 (77\%) of respondents stated that corruption was the most detrimental fraud. While as many as $41(19 \%)$ respondents stated that the abuse of assets was the most detrimental and $10(4 \%)$ respondents stated that the Financial Report Fraud was the most detrimental. Based on data from the survey, 4 out of 10 respondents $(40 \%)$ said that the losses incurred by fraudulent financial statements were above 10 billion rupiah

Several methods have been developed to understand and find fraud, but the condition of the company is growing and complex and the perpetrators of fraud are also getting smarter, besides that due to the rapid development of technology the perpetrators are also increasingly easy to get various information about the company. Crowe Howarth, an accounting, consulting and public technology company which the largest in the United States, in 2012 introduced a new theory that could be used more deeply to detect fraud in financial statements. The theory is pentagon fraud which is an extension of the fraud triangle by adding two other elements of fraud namely competence and arrogance. Competence in pentagon fraud has the same understanding as the capability stated in diamond fraud. 
The Agriculture Industry sector and the mining industry sector based on JASICA are included in the primary sector group [6]. One of the industrial sectors detected by financial statement fraud is a company engaged in the mining sector [12]. Judging from the 2018 Report To The Nations data on the Global Study on Occupational Fraud and Abuse published by the ACFE, it shows that there are 2,690 cases of fraud, the agricultural sector has 32 cases with a total loss of $\$ 136,000$ per case. While the mining sector has 27 cases found with a greater loss of $\$ 208,000$ per case.

The problems in this study were formulated as follows: How to Detect Financial Statement of Fraud with the Pentagon Fraud Method in Mining Sector Companies listed on the Indonesia Stock Exchange (IDX) for the period 2012 - 2018. Meanwhile, the objectives to be achieved from this study are as follows: Knowing Detection Fraud's Financial Statement with the Pentagon Fraud Method for Mining Sector Companies listed on the Indonesia Stock Exchange (IDX) for the period 2012 - 2018.

\section{Literature Review \\ 2.1 Fraud}

According to Mark F. Zimbelman et al [14] in the book Forensic Accounting defines fraud as a general term, and includes all kinds of ways that can be used with certain skills, chosen by an individual, to benefit from other parties by making a wrong representation. There are no fixed rules that can be issued as a general proportion in defining fraud, including surprises, deception, or devious and unnatural methods used to commit fraud. The only limitation in defining fraud is the things that limit human honesty.

The International Standards for the Professional Practice of Internal Auditting [11] defines fraud as "any illegal act characterized by deceit, concealment, or violation of trust. These acts are not dependent upon the threat of violance or physical force. Frauds are perpetrated by parties and obtain money, property, or services; to avoid payment or loss of services; or secure personal or business advantage ". The Association of Certified Fraud Examiners [2] explains that fraud against a company can occur or be carried out by parties from within the company itself which ACFE classifies such fraud as occupational fraud. The ACFE defines occupational fraud as the use of one's work for personal enrichment through deliberate abuse or the application of organizational resources or assets. ACFE shares three (3) main categories of fraud which are also called fraud trees.

\subsection{Financial Statement Fraud}

In 2013, the Indonesian Institute of Certified Public Accountants issued Audit Standards (SA) 240 concerning the Responsibilities of Auditors Related to Fraud in an Audit of Financial Statements, SA 240 explains that fraud in financial statements can occur due to intentions in presenting financial statements. There are two types of errors in the presentation of financial statements, namely presentation errors arising from financial reporting that contain fraud and misstatement arising from improper treatment of assets.

In SA 240 it is also explained that the risk of not being detected is due to a mistake that is caused by fraud. This is because fraud may involve sophisticated and carefully organized schemes designed to cover it, such as forgery, deliberately failing to record intentional misrepresentations of transactions or presentations to the auditor. Fraud done by management has a higher risk compared to fraud committed by employees to be undetected because management is in a position, either directly or indirectly to manipulate accounting records, present incorrect financial information, override control procedures designed to prevent similar fraud that can be done by other employees.

According to Mark F. Zimbelman et al [14] in the book Forensic Accounting, it is believed that there are nine (9) factors that emerge simultaneously that lead to fraud in financial statements which are referred to as perfect fraud storm, namely economic booms, deterioration in moral values, high expectations of analysis, high levels of debt, focus on rules rather than accounting principles, lack of auditor independence, greed and failure of educators. In the analysis of perfect fraud strom, it can be understood that the motivation to make a misstatement of financial statements is to support stock prices and offers to bonds and stocks remain high and to maximize bonuses received by management due to high stock prices. 


\subsection{Crowe's Fraud Pentagon Model}

In 2012, Jonathan T. Marks, CPA, CFE a forensic accountant and partner from Crowe, the largest public accounting, consulting and technology company in the United States developed a new way to understand the reasons for fraud. The new understanding is known as Crowe 'Fraud Pentagon Model (Figure 2.2), and is a development of the Cessey Fraud Triangle which is considered unable to describe the reasons for fraud due to the rapid development in the world of business and technology today.

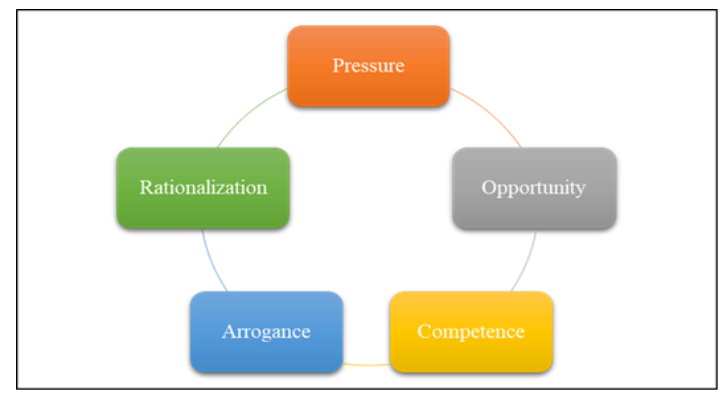

Figure 1. Crowe's Fraud Pentagon Model

\subsection{Earnings Management}

According to Subramanyam and Wild [8], earnings management is a deliberate management intervention in the process of determining earnings, usually to meet personal needs. There are many possible reasons behind earnings management, including increasing stock prices, increasing managerial compensation related to reported profits and efforts to obtain government subsidies [8]. In general, economic actors, governments, professional associations and other regulators, regard earnings management as opportunistic behavior of managers to play with the numbers in financial statements in accordance with the objectives to be achieved, so that they are categorized as fraud [9]. In the science of accounting, earnings management can be interpreted as an accounting trick where flexibility in preparing financial statements is used or utilized by managers who try to meet profit targets [5].

One approach used to detect earnings management is an aggregate accrual based approach which uses discretionary accruals to describe earnings management [9]. Dechow, Sloan and Sweeney developed the Jones model into a modified Jones model, in calculating the value of discretionary accruals. This model is widely used in accounting studies because it is considered to be the best model in detecting earnings management and provides the most robust or strong results [9].

\subsection{Relations of Financial Statement Fraud with Financial Stability}

SAS No. 99 defines financial stability as a condition that describes the stability of the company's financial position in a stable position. Financial statements can be used to assess the company's financial position, the results of the performance achieved by the company, and assess the company's financial prospects in the future [1]. The company's finance can be said to be stable by measuring its financial growth through company sales, the value of corporate earnings per year and the growth of company assets [7]. The number of total assets owned by the company is the main attraction for investors, creditors, and other decision holders [3]. In Siddiq et al [7] research, the growth of company assets is calculated by reducing the total assets in a given year with the total assets of the previous year then divided again by the previous year's total assets, which are formulated as follows:

$$
\mathrm{ACHANGE}=\mathrm{TA}_{\mathrm{it}}-\mathrm{TA}_{\mathrm{it}-1} / \mathrm{TA}_{\mathrm{it}-1}
$$

\subsection{Relations of Financial Statement Fraud with nature of industry}

Nature of industry is the ideal state of a company in an industrial environment [13]. In ISA 240 about "The Auditor's Responsibilities Relating to Fraud in Audit of Financial Statement" states that the nature of industry provides an opportunity for financial statement fraud. Nature of industry is the ideal state of a company in an industrial environment. In ISA 240 it is explained that one of the factors of the nature of a company that can lead to fraud is assets, liabilities, income, or expenses based on estimates 
that involve subjective valuations or uncertainties that are difficult to strengthen. Accounts receivable is a form of nature of industry that can be responded to with different reactions from each company manager [4].

According to Skousen et al in Faradiza [4] accounts receivable are related to estimates of uncollectible receivables whose amounts are subjective, so management can use these accounts as a tool to manipulate financial statements, which can be calculated using the formula:

$$
\text { RECEIVABLE }=\left(\text { Reveivable }_{\mathrm{t}} / \text { Receivable }_{\mathrm{t}-1}\right)-\left(\operatorname{Sales}_{\mathrm{t}} / \text { Sales }_{\mathrm{t}-1}\right)
$$

\subsection{Relation of Financial Statement of Fraud with Accrual Based Accounting}

Accrual-based accounting attempts to record all financial influences that occur in a transaction and event that have cash consequences for the period concerned, not only when cash is received or paid in cash [9]. Transactions that are regulated by utilizing freedom to determine the value of accounting estimates are transactions that are not easy for the report user to know [9]. Total accruals will affect fraud in financial statements because accruals are strongly influenced by management decisions in rationalizing financial statements [4]. In general, earnings management can be done because the basis for recording the transactions used is accrual, which is recording transactions carried out without having to have cash receipts or cash outlays [9]. Based on the calculation of the modified Jones model [9], the accrual value of a company can be calculated using a formula:

$$
\mathrm{TAC}=\text { NIit }- \text { CFOit }
$$

\subsection{Relations of Financial Statement Fraud with change in CEO}

Financial report fraud is usually carried out by individuals who are in the highest position in the organization, and carried out in the name of the organization, not against the organization [14]. According to Wolfe and Hermanson in Zellin [13] indications of fraud can occur if carried out by the right people and understand and can take advantage of existing opportunities. In the Bawakes study [3] there are six components in competence, including: positioning, intelligence, confidence (ego), coercion skills, effective lying / deceit, and stress management (stress management).

According to Wolfe and Hermanson in Bawakes [3], that changes in directors are able to cause stress periods that have an impact on the opening of opportunities for fraud. Fraud management actors usually have a high position in the company, for example the Chief Executive Officer (CEO). According to Skousen et al in Faradiza [4], CEOs who will retire or expire will carry out a strategy of maximizing the amount of profit reporting to increase the amount of bonus that will be received later.

\subsection{Financial Statement Relationship Fraud with The Dualism Position of The Chief Executive Officer (CEO) of The Company}

According to Wolfe and Hermanson in Aprilla [1] states that the position of Chief Executive Officer (CEO), directors, and other division heads is a determining factor for fraud, by relying on its position which can influence others and with their ability to utilize circumstances that can facilitate fraud. Dualism position is a condition where a member of the board of directors has another position both inside and outside the company [13]. Based on the Financial Services Authority Regulation No.33 / POJK.04 / 2014 concerning Directors and Board of Commissioners of Issuers or Public Companies a member of the board of directors is permitted to concurrently hold positions with the following conditions:

1. The members of the board of directors are at most one (1) issuer or other public company.

2. Members of the Board of Commissioners are at most 3 (three) issuers or other public companies

3. The committee members are at most 5 (five) committees in the issuer or public company where the relevant member also serves as a member of the board of directors or board of commissioners.

\subsection{Hypothesis}

\subsubsection{Pressure in the category of financial stability affects Financial Statement Fraud}

Management is pressured to be able to maintain a stable financial position so that it can be trusted by interested parties. One of the ways in which the management of the company remains stable is to show that the company has good asset growth every year. However, if the company's performance is not in 
line with expectations, the possibility of fraud will arise because of how management must maintain the company's financial stability. The growth of a company's assets can be calculated by using a total comparison ratio for 2 years. This description can formulate the following hypothesis:

$\mathrm{H}$ : Pressure in the relation category of financial stability affects Financial Statement Fraud

\subsubsection{Opportunity in the category nature of industry affects Financial Statement Fraud}

In relation to external auditors, management of an organization will decide to commit fraud if it sees an opportunity to do so if the external auditor examining does not have adequate or easy ability to deceive. The quality of an auditor can be seen through the selection of a Public Accounting Firm appointed by the organization to conduct an audit, namely the KAP is included in BIG4 or not included in BIG4. This description can formulate the following hypothesis:

H2: Opportunity in the category of external auditor quality affects Fraud's Financial Statement.

\subsubsection{Rationalization in the total acrual ratio category affects Fraud's Financial Statement}

Recording of transactions based on accruals is very vulnerable to fraudulent actions because the estimated value of a transaction is only based on estimates from the management of the company. Companies that use accrual-based transactions will cause subjective judgments taken by management to be justified, so that fraud occurs is justified. This description can formulate the following hypothesis:

H3: Rationalization in the total accrual ratio category affects Fraud's Financial Statement

\subsubsection{Competence in the change in category of CEO influences Fraud's Financial Statement}

CEO turnover shows instability in the organization so companies need to carry out stress management to improve the performance of directors to improve company performance. Placing people who have better abilities to manage companies can be an indication of fraud committed by previous people. This description can formulate the following hypothesis:

H4: Competence in the change in category CEO influences Fraud's Financial Statement.

\subsubsection{Arrogance in the dualism position of CEO category affects Fraud's Financial Statement}

Arrogance can be interpreted as acts of arrogance that lead to only being selfish and looking at others who are below them. A management who has such characteristics is very likely to commit fraud to fulfill his personal desires. One way to see this is to pay attention to the multiple positions of a CEO with the same position in more than two companies both in subsidiaries or other companies. This description can formulate the following hypothesis:

H5: Arrogance in the dualism position of CEO category affects Fraud's Financial Statement.

\section{Research Methods}

The population taken in this study are all companies listed on the Indonesia Stock Exchange (IDX) in the period 2012-2018 with samples taken are companies engaged in the mining industry sector. Due to the large number of samples and not necessarily all samples can be used in this study, the method used to determine the sample used is purposive sampling method.

\subsection{Independent Variable $(\mathrm{X})$}

Pressure that can lead to fraud in financial statements is seen in the business management category of an organization to maintain the company's financial position to remain good. To see financial stability is used the ratio of total assets for 2 years, which according to Siddiq et al [7] can be calculated by the formula:

$$
\mathrm{ACHANGE}=\mathrm{TA}_{\mathrm{it}}-\mathrm{TA}_{\mathrm{it}-1} / \mathrm{TA}_{\mathrm{it}-1}
$$

After that the value of ACHANGE is measured by a dummy variable, that is value 1 for companies with asset growth which is well marked ACHANGE positive sign and value 0 for company with asset growth which is not well marked with ACHANGE value marked negative.

Oppurtunity in this study, oppurtunity (Opportunity) that can cause fraud (fraud) on financial statements seen in the nature of industry category is calculated using the ratio of total accounts. 
According to Skousen in Faradiza [4] the ratio of total accounts receivable can be calculated using the formula:

$$
\text { RECEIVABLE }\left(\text { Reveivable }_{\mathrm{t}} / \text { Receivable }_{\mathrm{t}-1}\right)-\left(\operatorname{Sales}_{\mathrm{t}} / \text { Sales }_{\mathrm{t}-1}\right)
$$

Then the RECEIVABLE value is proxied by the dummy variable which is value 1 for companies with high total receivables which are marked with a positive sign, and a value of 0 for companies with low total receivables which are marked with a negative sign.

Rationalization In this study, rationalization which can lead to fraud in financial statements is seen in the category of total acrual ratios. Based on the calculation of the modified Jones model [9], the accrual value of a company can be calculated using the formula:

$$
\mathrm{TAC}=\mathrm{NI}_{\mathrm{it}}-\mathrm{CFO}_{\mathrm{it}}
$$

Then, the value of TAC is proxied by the dummy variable which is given a value of 1 for the company with an accrual value showing that profits are either marked with a positive sign, and a value of 0 for the company with an accrual value shows a poor profit marked with a negative sign.

Competence that can lead to fraud in financial statements is seen in the change in CEO category, which is proxied by a dummy variable that is given a value of 1 for companies that make changes to the president director or director for the period 2012-2018, and 0 for companies that do not change of president director or director for the period 2012-2018.

Arrogance that can lead to fraud in financial statements is seen in the category dualism position of a CEO as measured by a dummy variable that is given a value of 1 for companies whose directors or directors hold concurrent positions in more than 1 company as a member of the board of directors, and 0 for companies whose president directors or directors do not hold concurrent positions in more than 1 company as directors.

\subsection{Dependent Variable (Y)}

In this study the dependent variable used is financial statement fraud that is proxied by earnings management. To be able to do the calculation of the measurement of discretionary accrual which is the determination of accruals whose value is based on decisions from the management of the organization. In this study calculated using the Jones modification model, calculation of the modified Jones model [9] is as follows:

Calculate total accruals (TAC), that is profit after taxed year $\mathrm{t}$ minus the operating cash flow in year $t$ by the formula:

\section{TAC $=$ NIit - CFOit}

Then total accrual (TA) is estimated using Ordinary Least Square (OLS) which is formulated as follows:

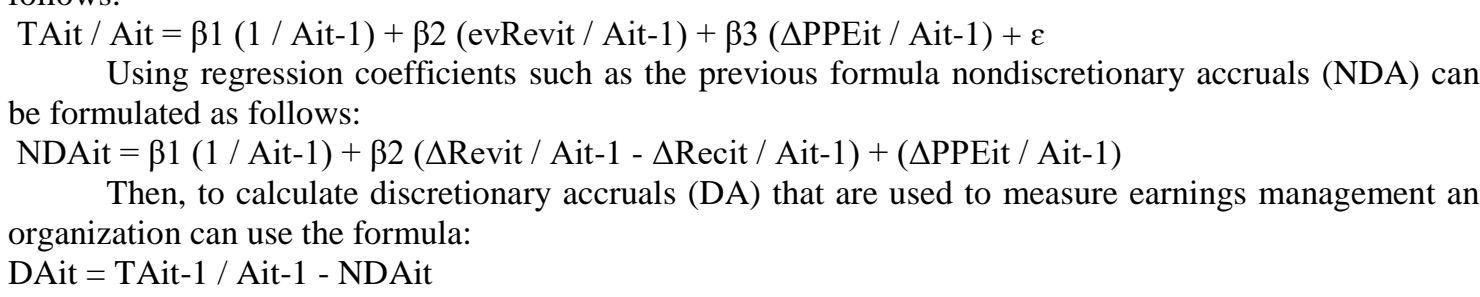

\subsection{Data Analysis Method}

This study uses SPSS 25 computer application program to analyze the effect of the relationship between the independent variables and the dependent variable with the logistic regression model as follows:

$\operatorname{lnDA}_{i t} / 1-\mathrm{DA}_{\mathrm{it}}=\alpha+\beta_{1} \mathrm{ACHANGE}+\beta_{2} \mathrm{RECEIVABLE}+\beta_{3} \mathrm{ACCRUAL}+\beta_{4} \mathrm{CEOCHANGE}+\beta_{5} \mathrm{CEOCP}+\mathrm{e}$ 
The stages used in Logistic regression are the feasibility test of the regression model, Overall model fit, Assessing the coefficient of determinant, Table Matrix of Clarification and Logistic regression coefficient test, Wald test and G Test.

\section{Results and Discussion}

Based on the determination of the sample by purposive sampling method, a sample of 15 companies was obtained for each year so that there were 105 data used in this study.

Table 1. Logistic Regression Coefficient Test Result

\begin{tabular}{lll}
\hline \multirow{2}{*}{$\begin{array}{l}\text { Step } \\
\mathbf{1 a}\end{array}$} & ACHANGE & $\mathbf{B}$ \\
\cline { 2 - 3 } & RECEIVABLE & 0,71 \\
\cline { 2 - 3 } & ACCRUAL & 0,393 \\
\cline { 2 - 3 } & CEOCHANGE & $-0,391$ \\
\cline { 2 - 3 } & CEOCP & $-0,663$ \\
\cline { 2 - 3 } & Constant & 0,318 \\
\hline
\end{tabular}

Based on table 4.11 it is known that the significance level of mdel is 0.043 , meaning that it is smaller than $\alpha=0.05$ so that H0 cannot be rejected or can be said to be accepted, then the independent variable model is worth explaining the dependent variable.

Based on the results of data analysis that has been done, it can be further elaborated as follows:

$\operatorname{lnDAit} / 1$-DAIT $=0,318+0,71 \mathrm{ACHANGE}+0,393 \mathrm{RECEIVABLE}+0,814 \mathrm{ACCRUAL}-$ $0,391 \mathrm{CEOCHANGE}-0,663 \mathrm{CEOCP}+\varepsilon$

From the above equation can be seen the direction of influence of each independent variable on the dependent variable seen from the regression coefficient value (B) of each independent variable. Regression coefficients that are positively marked have a direction of influence that is in line with financial statement fraud (DAit), while the regression coefficient that has a negative direction has the opposite direction to financial statement fraud (DAit).

Table 2. Wald Test

\begin{tabular}{lll}
\hline \multirow{2}{*}{ Step 1a } & ACHANGE & Sig. \\
\cline { 2 - 3 } & RECEIVABLE & 0,108 \\
\cline { 2 - 2 } & ACCRUAL & 0,078 \\
\cline { 2 - 2 } & CEOCHANGE & 0,384 \\
\hline & CEOCP & 0,146 \\
\hline Constant & 0,642
\end{tabular}

Based on table 4.10 it can be concluded as follows:

1. H1: Pressure (ACHANGE) in the category of financial stability affects Fraud's FinancialStatement Pressure free variable (ACHANGE) shows a significance value of 0.108 , meaning that it is greater than $\alpha=0.05$ so $\mathrm{H} 1$ is rejected and in this study proves that Pressure in the financial stability category does not significantly influence Fraud's Financial Statement.

2. H2: Opportunity (RECEIVABLE) in the nature of industry category affects Fraud's Financial Statement.

The independent oppurtunity variable (RECEIVABLE) shows a significance value of 0.374 which means that it is greater than $\alpha=0.05$ so $\mathrm{H} 2$ is rejected and in this study proves that the opportunity in the nature of industry category does not significantly influence Fraud's Financial Statement. 
3. H3: Rationalization (ACCRUAL) in the category of total accrual ratio affects the Financial Statement of Fraud

Free rationalization variable (ACCRUAL) shows a significant value of 0.078 meaning the same as $\alpha$ $=0.05$ so that $\mathrm{H} 3$ can be accepted and in this study proves that the Rationalization in the total accrual ratio category significantly influences Fraud's Financial Statement.

4. H4: Competence (CEOCHANGE) in the change in category CEO influences Fraud's Financial Statement

The independent variable competence (CEOCHANGE) refers to a significance value of 0.146, which means that it is greater than $\alpha=0.05$ so that $\mathrm{H} 4$ is rejected and in this study proves that Competence in the change in CEO category does not have a significant influence on fraudulent Financial Statement

5. H5: Arrogance (CEOCP) in the Dualism position of CEO category affects Fraud's Financial Statement

Arrogance free variable (CEOCP) shows a significance value of 0.642 which means that it is greater than $\alpha=0.05$ so that H5 is rejected and in this study shows that Arrogance in the dualism position of CEO category does not have a significant influence on Fraud's Financial Statement.

Table 3. G Test

\begin{tabular}{ccc}
\hline \multirow{2}{*}{ Step 1 } & & Sig. \\
\cline { 2 - 3 } & Step & 0,043 \\
\cline { 2 - 3 } & Block & 0,043 \\
\cline { 2 - 3 } & Model & 0,043 \\
\hline
\end{tabular}

Based on table 4.11 it is known that the significance level of mdel is 0.043 , meaning that it is smaller than $\alpha=0.05$ so that $\mathrm{H} 0$ cannot be rejected or can be said to be accepted, then the independent variable model is worth explaining the dependent variable.

Based on the results of data analysis that has been done, it can be further elaborated as follows:

\subsection{Effect of Pressure (ACHANGE) on Financial Statement Fraud (DAit)}

Based on the test of the logistic regression coefficient which can be seen in table 4.8, it shows that the independent variable ACHANGE has a positive direction of 0.71 and a probability of $73.65 \%$. While based on the Wald test shows a significance level of 0.1028 which is $\alpha=0.05$ so that it does not significantly influence and cannot detect the occurrence of dependent variable financial statement fraud (DAit) in mining sector companies listed on the Indonesia Stock Exchange (BEI) period 2012 to 2018.

This happens because the management of the company does not feel the need to manipulate the growth of company assets because in the business world the rise and fall of asset values is a natural thing so that company management is not under pressure to commit fraud so that the company's financial position is in a position that stable which can be seen from good total asset growth. This study proves that company management prefers to address the company's financial stability in accordance with existing conditions without having to manipulate its financial statements.

Previous research conducted by Faradiza [4], Bawakes [3], Siddiq et al [7], Aprilla [1] and Zelin [13] have different results in research they stated that pressure in the financial stability category seen from the growth of total assets for 2 years (ACHANGE) had a significant effect on the financial statement of fraud, this happened because the object of research was different so that the results were also different. The companies used in the previous research did get pressure to maintain financial stability then commit fraud, but this study that took objects to mining sector companies showed the opposite results.

\subsection{Influence of Opportunity (RECEIVABLE) on Financial Statement (DAit)}

Based on the test of the logistic regression coefficient which can be seen in table 4.8, it shows that the RECEIVABLE independent variable has a positive direction of 0.393 and a probability of $67.06 \%$. Whereas based on the wald test shows a significance level of 0.374 which $>\alpha=0.05$ so that it does not significantly influence and cannot detect the occurrence of dependent variable financial statement fraud 
(DAit) in mining sector companies listed on the Indonesia Stock Exchange (BEI) for the year 2012 to 2018.

This happened because the company management did not manipulate the total receivables received, because the company has an industrial nature that does have a small uncollectible risk because the company implements risk management to minimize the risk of uncollectible receivables which can reduce company revenue. This research proves that the opportunity to cheat by raising the value of accounts receivable so that it has an impact on large profits is not done because it is not the nature of the industry of the company which is the object of this research that has implemented risk management so as to minimize the occurrence of uncollectible accounts. This is supported by research conducted by Zellin [13] which in the study stated that Oppurtunity in the nature of industry category did not significantly influence financial statement fraud seen from earnings management.

\subsection{Effect of Rationalization (ACCRUAL) on Financial Statement Financial (DAit)}

Based on the test of the logistic regression coefficient which can be seen in table 4.8 , it shows that the independent variable CEA has a positive direction which is 0.814 and the probability is $75.62 \%$. While based on Wald test shows a significance level of 0.078 which $>\alpha=0.05$ so that it does not significantly influence and can not detect the occurrence of dependent variable financial statement fraud (DAit) in mining sector companies listed on the Indonesia Stock Exchange (IDX) year period 2012 to 2018.

This is because the value of total accruals is not the result of manipulation by the management of the company to justify the management of profits made but rather the actual condition of the company. This research proves that the Rationalization in the category of total accrual ratio does not significantly influence financial statement fraud seen from earnings management. This is supported by research conducted by Faradiza [4] which in the study also states that the Rationalization in the category of total accrual ratio does not significantly influence financial statement fraud seen from earnings management.

\subsection{The Effect of Competence (CEOCHANGE) on Financial Statement (DAit)}

Based on the test of the logistic regression coefficient which can be seen in table 4.8, it shows that the CEOCHANGE independent variable has a negative direction which is $-0,391$ and a probability of $48.17 \%$. Whereas based on the wald test shows a significance level of 0.384 which $>\alpha=0.05$ so that it does not significantly influence and cannot detect the occurrence of dependent variable financial statement fraud (DAit) in mining sector companies listed on the Indonesia Stock Exchange (BEI) for the year 2012 to 2018 .

This can happen because the replacement of a president director or director is not solely because of improvements in the performance of the company's directors but is a natural thing because each member of the board of directors can resign or his term of office has ended so that changes are made and do not indicate performance improvement of a company director. This is supported by the Zellin study [13], Siddiq et al [7], and Bawakes [3] which in the study also stated that Competence in the change in CEO category did not significantly influence financial statement fraud seen from earnings management.

\subsection{Arrogance Effect (CEOCP) on Financial Statement (DAit)}

Based on the test of the logistic regression coefficient which can be seen in table 4.8 , it shows that the independent variable CEOCP has a negative direction which is -0.663 and a probability of $41.45 \%$. While based on the Wald test shows a significance level of 0.146 which is $>\alpha=0.05$ so that it does not significantly influence and cannot detect the occurrence of the dependent variable financial statement fraud (DAit) in mining sector companies listed on the Indonesia Stock Exchange (IDX) for the year 2012 to 2018 .

This can happen because of the government or institution that has the authority to do so that requires every company that goes public to implement Good Corporate Governance (GCG) so that even though a CEO is arrogant in nature who wants a lot of positions not to cheat by manipulating company financial statements. This study proves that Arrogance in the dualism category of CEO position does not significantly influence financial statement fraud seen from earnings management. This is supported by the research of Zelin [13] which in his research stated that arrogance in the dualism category of CEO position did not significantly influence financial statement fraud seen from earnings management. 


\section{Conclusion and Suggestion}

From the results of the study using logistic regression analysis techniques using the SPSS 25 analysis tool it can be concluded that the regression model used can predict the observed value, the model used is good and fit with the data, the independent variable is only able to explain $13.9 \%$ of the dependent variable namely the financial fraud statement and $86.1 \%$ are explained by variables outside the study, overall the classification classification regression accuracy of observational data is $65.7 \%$ and independent variable pressure (ACHANGE), independent variable oppurtunity (RECEIVABLE), independent variable rationalization (ACCRUAL), competence (CEOCHANGE), and arrogance free variables (CEOCP) were unable to detect financial statement fraud in mining companies listed on the Indonesia Stock Exchange (IDX) for the period 2012 to 2018.

The obstacle in this study is that the variables used have not been able to explain the dependent variable, this is because the pentagon fraud model is a model that is seen based on reasons arising from within a person so that it will be very difficult to be found in audited financial statements or reports annual company. Based on the results of the research that has been explained in the conclusions obtained, there are several suggestions that can be done, namely For further research, it is expected to be able to use other factors that can be used to detect the occurrence of fraud in the financial statements by using perfect fraud strom which states that there are (9) factors that emerge simultaneously that lead to fraud in financial statements, namely economic boom, deterioration of moral values, high expectations of analysis, high levels of debt, focus on rules rather than accounting principles, lack of auditor independence, greed, and failure of educators [14].

\section{References}

[1] Aprilla, Vivi R.,. "Pengaruh financial stability, external pressure, ineffective monitoring, change in auditor,change in director dan frequent number of ceo's picture terhadap financial statement fraud dalam perspektif fraud pentagon (studi empiris pada perusahaan manufaktur yang terdaftar Di BEI Tahun 20112016)". JOM FEB. Volume: 1 Edisi: 1 (Januari - Juni 2018). (2017)

[2] Association of Certified Freaud Examinners. "Report to the nation on occupational fraud and abuse (2018 global fraud study)”. Di https://www.acfe.com. Diakses pada 1 Maret 2019. (2018)

[3] Bewekes, Helda F. "Pengujian teori fraud pentagon terhadap fraudulent financial reporting (studi empiris pada perusahaan yang terdaftar di bursa efek indonesia tahun 2011-2015)". Jurnal Akuntansi \& Keuangan Daerah. Volume: 13, Nomor: 1, Mei 2018: 114-134. (2016)

[4] Faradiza, Sekar A. "Fraud pentagon dan kecurangan laporan keuangan". EkBis: Jurnal Ekonomi dan Bisnis Fakultas Ekonomi dan Bisnis Islam Universitas Islam Negeri Sunan Kalijaga Yogyakarta. Vol. 2, No. 1. Halaman 1 - 22. (2016)

[5] Hery. Analisis kinerja manajemen. Di https://books.google.co.id. Diakses pada 27 Maret 2019. MHTML Doc. (2015)

[6] Indonesian Stock Exchange. "Indeks harga saham”. Di http://www.idx.co.id. Diakses 1 Maret 2019. (2019)

[7] Siddiq, Faiz R., Achyani, F., dan Zilfikar. "Fraud pentagon dalam mendeteksi financial statement fraud". Seminar Nasional dan The 4th Call for Syariah Paper. Peran Profesi Akuntansi Dalam Penanggulangan Korupsi. (2016)

[8] Subramnyam, K. R., dan Wild, Jhon J. Analisis laporan keuangan (financial statement analysis) Edisi 10 Buku 1. Dewi,Yanti, Penerjemah. Jakarta: Salemba Empat (2014)

[9] Sulistyanto,H. Sri. Manajemen laba (teori dan model empiris). Di https://books.google.co.id. Diakses pada 27 Maret 2019. MHTML Doc. (2008)

[10] Suyono, E. "Berbagai model pengukuran earnings management: mana yang benar " Di www.researchgate.net. Diakses pada 1 Maret 2019. MHTML Doc. (2017)

[11] The Institute of Internal Auditors. "International standards for the profesionals practice of internal auditing 2017”. Di https://na.theiia.org. Diakses pada 1 Maret 2019. (2017)

[12] Vivianita, Alfa dan Indudewi, Dian. "Financial statement fraud pada perusahaan pertambangan yang dipengaruhi oleh fraud pentagon theory (studi kasus di perusahaan tambang yang terdaftar di BEI tahun 2014-2016)". Dinamika Sosial Budaya. Vol 20, No. 1, Juni 2018, pp 1-15. Dipublikasikan. (2017) 
[13] Zellin, Cintia. "Analisis fraud pentagon dalam mendeteksi kecurangan laporan keuangan dengan menggunakan fraud score model". Fakultas Ekonomi. Universitas Islam Indonesia. Yogyakarta. Skripsi. (2018)

[14] Zimbelman, Mark F., Albercht, W. Steve., dan Albercht, Chad O. Akuntansi forensik (accounting forensic). Puspitasari, N., Suhernita., dan Saraswati,R., Penerjemah. Jakarta: Salemba Empat. (2017) 